\title{
THE INFLUENCE OF METEOROLOGICAL CONDITIONS ON THE START OF THE HAZEL (Corylus L.) POLLEN SEASON IN LUBLIN, 2001-2009
}

\author{
Krystyna Piotrowska1, Bogusław Michał Kaszewski ${ }^{2}$ \\ ${ }^{1}$ Department of Botany, University of Life Sciences, Akademicka 15, 20-095 Lublin, Poland \\ ${ }^{2}$ Department of Meteorology and Climatology,Maria Skłodowska-Curie University, \\ al. Kraśnicka 2cd, 20-048 Lublin, Poland \\ e-mail: krystyna.piotrowska@up.lublin.pl
}

Received: 2.09.2009

\begin{abstract}
Early spring flowering plants show large differences in the start dates of pollen emission due to high weather variability in the preceding period. In the present study, the influence of meteorological conditions on the start date of the hazel pollen season in Lublin in the years 2001-2009 was investigated. The aeropalynological study was carried out by the volumetric method using a Lanzoni VPPS 2000 sampler. The start of the hazel pollen season was determined using the $98 \%$ method. The differences in particular years of the study were over two months. Hazel pollen grains were recorded earliest in 2007, since from 13 January, and latest in 2003, from 18 March. It was found that accumulated 5-day mean temperature before the season affects the onset of the pollen season. As a result of multiple regression analysis, a statistical model was derived, which shows with great accuracy the relationship of the start of the hazel pollen season with total precipitation and the number of winter days.
\end{abstract}

Key words: Corylus, aerobiology, start pollen season, meteorological factors, regression model, Lublin

\section{INTRODUCTION}

Pollen allergy is a seasonal disease, and its symptoms are associated with the presence of airborne pollen grains. Therefore, it is very important to warn early allergists and their patients about the approaching period of plant pollen shedding. Monitoring the start of plant flowering and pollen emission is also of great significance for phytophenology, flowering ecology and meteorology. Predicting the start of pollen shedding of early spring flowering plants is particularly difficult, since they are exposed to abrupt weather changes. The greatest differences in the start of pollen seasons relate to these taxa (P u c, 2007; W e ry s z k o-Ch mielew s k a and $\mathrm{R}$ a p i e j k o , 2007). It has been found that earlier flowering dates as well as increased concentrations of airborne pollen grains of some plant taxa are related to the observed global warming (F r e i, 1998; E m b e r 1 i n et al. 2007). Longer pollen seasons and larger pollen production are, among other things, responsible for an increase in pollen allergy incidence. In Poland, in addition to alder and birch, hazel belongs to the most important plants causing pollinosis in the spring period. Allergy to hazel pollen affects $21 \%$ of pollen allergy sufferers (H o f m a n and M i ch a li k, 1998). The possibility of predicting the pollen season start date is very essential for allergists and their patients. In many countries research is conducted in order to develop predictive models which enable pollen season dates to be predicted (e.g. A d a m s-Groom et al. 2002; Rodriguez-Rajo et al. 2004; Dąbrowska$\mathrm{Z}$ a p a r t, 2008). Such models generally incorporate meteorological data which are considered to be the most important factors affecting the variability in season start and end dates as well as in airborne pollen concentrations.

Hazel pollen grains contain allergens with very strong allergenic properties which exhibit cross reactions with pollen allergens of plants belonging to the order Fagales (Matthiesen et al. 1991; Knox and Suphioglu, 1996). Allergy to hazel pollen is usually accompanied by hypersensitivity to alder and birch pollen (Filon et al. 2000; R a pi j k o, 2007).

The aim of the present study was to determine which of the meteorological factors has the largest influence on the onset of the hazel pollen season. During the study, an attempt was made to develop a regression model which would be helpful in predicting the start of the pollen season in Lublin. 


\section{MATERIALS AND METHODS}

The aerobiological study was conducted in Lublin in the years 2001-2009. For airborne hazel pollen counts, a Lanzoni VPPS 2000 sampler was used, which was placed on the roof of a building at a height of $18 \mathrm{~m}$ above ground level $\left(\varphi=51^{0} 14^{\prime} \mathrm{N} ; \lambda=22^{0} 32^{\prime} \mathrm{E} ; \mathrm{H}=197\right.$ $\mathrm{m}$ a.s.l.). Microscopic analysis of the pollen collected on the tape was performed on 4 horizontal sweeps of the slide. Pollen concentration was expressed as the mean daily number of pollen grains per $1 \mathrm{~m}^{3}$ of air. The $98 \%$ method was used to calculate the start of the hazel pollen season (Fre n g u e $11 \mathrm{i}$ et al. 1991).

Meteorological data came from the Meteorological Observatory of the Meteorology and Climatol- ogy Department, the Maria Curie-Sklodowska University in Lublin, located in the city centre in a tree-covered city centre square $\left(\varphi=51^{0} 15^{\prime} \mathrm{N} ; \lambda=22^{0} 34^{\prime} \mathrm{E}\right.$; $\mathrm{H}=195.3 \mathrm{~m}$ a.s.1.), at a distance of about $1.5 \mathrm{~km}$ from the pollen sampling site.

Mean annual air temperature in Lublin (19512007 ) is $8.2^{\circ} \mathrm{C}$ (Tab. 1). The coldest month is January, with mean temperature of $-2.8^{\circ} \mathrm{C}$, and the warmest one July with the mean of $18.9^{\circ} \mathrm{C}$. Mean annual total precipitation in Lublin for the same period is $546 \mathrm{~mm}$. On an annualised basis, the lowest annual precipitation totals are observed in January and February (28 $\mathrm{mm}$ in each month), and the highest in July (80 mm).

Table 1

Annual air temperature and precipitation patterns in Lublin (1951-2008).

\begin{tabular}{|c|c|c|c|c|c|c|c|c|c|c|c|c|c|}
\hline & I & II & III & IV & V & VI & VII & VIII & IX & $X$ & XI & XII & Year \\
\hline $\begin{array}{c}\text { Temperature } \\
\text { of air } \\
{\left[{ }^{\circ} \mathrm{C}\right]}\end{array}$ & $-2,8$ & $-1,9$ & 2,0 & 8,5 & 14,1 & 17,4 & 18,9 & 18,2 & 13,5 & 8,6 & 3,2 & $-0,8$ & 8,2 \\
\hline $\begin{array}{c}\text { Total } \\
\text { precipitation } \\
{[\mathrm{mm}]}\end{array}$ & 28 & 28 & 29 & 39 & 55 & 64 & 80 & 65 & 52 & 37 & 37 & 33 & 546 \\
\hline
\end{tabular}

To estimate the influence of meteorological factors on the start date of the hazel pollen season, the following meteorological data were used: mean $\left(\mathrm{t}_{\text {mean }}\right)$, minimum $\left(\mathrm{t}_{\min }\right)$ and maximum $\left(\mathrm{t}_{\max }\right)$ daily air temperature, mean daily relative humidity (f), daily total precipitation ( $p$ ), mean daily cloud cover ( $n$ ) and mean daily wind speed (v). In the present study, the statistical correlation was examined between the start date of the hazel pollen season and the abovementioned weather elements and their characteristics. The analysis covered the period from 1 October to the start date of the hazel pollen season. In order to develop the statistical model, the multiple regression method was applied (S t a n is z, 2000).

\section{RESULTS}

Over the 9-year study period, the start of the hazel pollen season was noted between 13 January
(2007) and 18 March (2003), on the average 10 February. The difference between the extreme dates was over two months (64 days) (Fig. 1).

Great variability in the pollen season start dates was accompanied by large year-to-year variations in different meteorological elements in the period preceding pollen emission (Tab. 2). For example, in the year 2007, with the earliest pollen season start date, in the period from 1 October of the year preceding pollen emission to the date of pollen shedding mean air temperature was $6.8^{\circ} \mathrm{C}$ and there were only 5 days with mean daily temperature below $0^{\circ} \mathrm{C}$ (that is, winter days), whereas in the period preceding the latest pollen season start date (2003), mean temperature was $-0.2^{\circ} \mathrm{C}$ and there were as many as 85 winter days. 


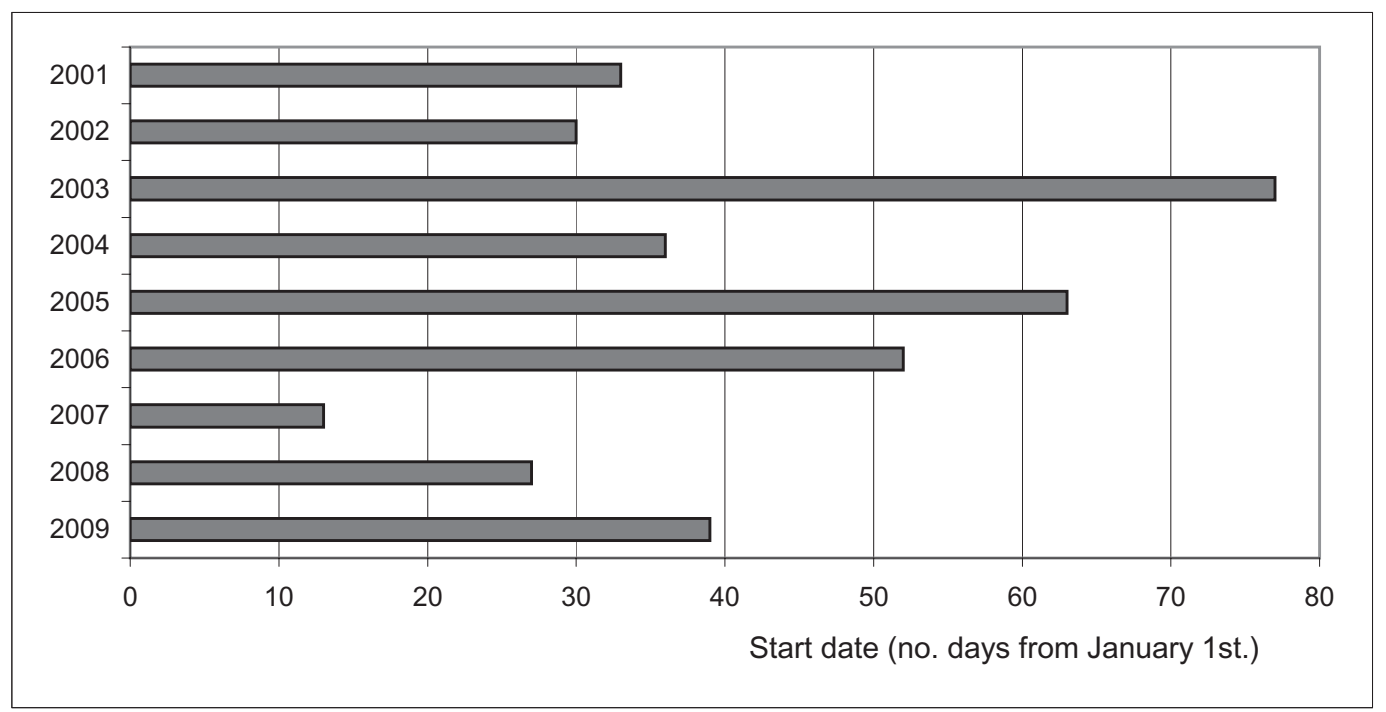

Fig. 1. Comparison of the start dates of the hazel pollen seasons in the years 2001-2009.

Table. 2

Selected temperature and precipitation characteristics in Lublin in the period from 1 October until the onset of the pollen season.

\begin{tabular}{|c|c|c|c|c|c|c|c|}
\hline \multirow{2}{*}{ Season } & \multicolumn{3}{|c|}{ Temperature $\left[{ }^{\circ} \mathrm{C}\right]$} & \multirow{2}{*}{$\begin{array}{c}\text { Total } \\
\text { precipitation } \\
{[\mathrm{mm}]}\end{array}$} & \multirow{2}{*}{$\begin{array}{c}\text { Number } \\
\text { of days } \\
\text { with mean } \\
\text { temperature }<0\end{array}$} & \multirow{2}{*}{$\begin{array}{c}\text { Number of } \\
\text { days with max } \\
\text { temperature }<0\end{array}$} & \multirow{2}{*}{$\begin{array}{c}\text { Number of } \\
\text { days with min } \\
\text { temperature } \\
<0\end{array}$} \\
\hline & Mean & Max & Min & & & & \\
\hline $2000 / 2001$ & 4,9 & 2,3 & 7,9 & 130 & 25 & 15 & 40 \\
\hline $2001 / 2002$ & 1,7 & $-1,0$ & 4,3 & 87 & 55 & 43 & 65 \\
\hline $2002 / 2003$ & $-0,2$ & $-2,8$ & 2,6 & 178 & 85 & 65 & 103 \\
\hline $2003 / 2004$ & 2,0 & $-0,2$ & 4,4 & 116 & 39 & 28 & 63 \\
\hline $2004 / 2005$ & 2,7 & 0,4 & 5,1 & 182 & 50 & 28 & 68 \\
\hline $2005 / 2006$ & 0,7 & $-2,0$ & 5,6 & 118 & 67 & 51 & 86 \\
\hline $2006 / 2007$ & 6,8 & 4,3 & 9,7 & 70 & 5 & 2 & 16 \\
\hline 2007/2008 & 2,7 & 0,5 & 5,0 & 74 & 30 & 27 & 54 \\
\hline 2008/2009 & 3,7 & 1,4 & 6,3 & 133 & 38 & 24 & 51 \\
\hline
\end{tabular}



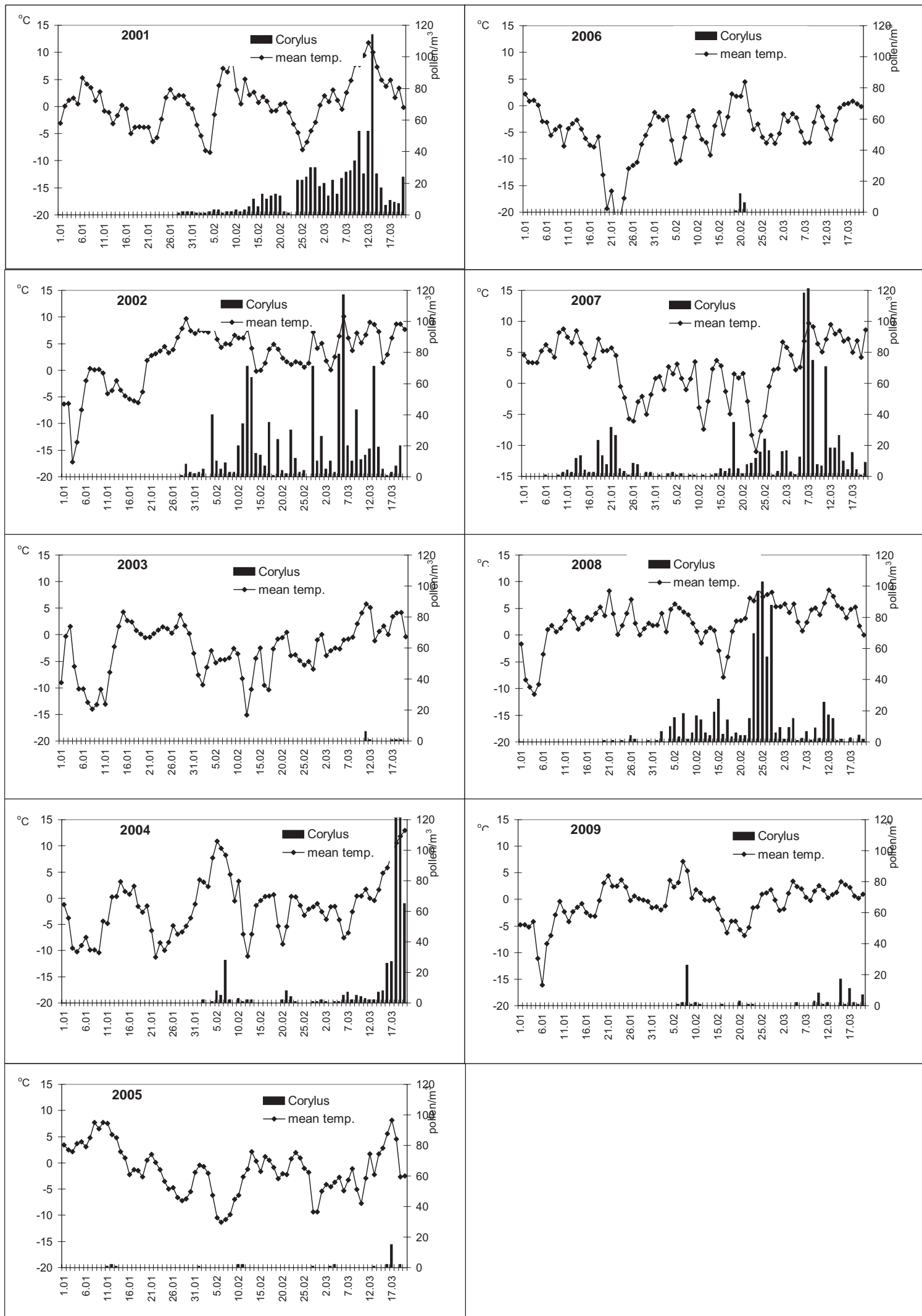

Fig. 2. Variation of daily mean temperature from January to the start of Corylus pollen season in Lublin, 2001-2009. 
The influence of daily air temperature on the start of the hazel pollen season is illustrated by air temperature patterns in particular years of the study (Fig. 2 ). Already visual analysis suggests that temperature on the days immediately preceding the pollen season plays an important role in this case.

In order to determine the influence of temperature on the pollen season start date, coefficients of linear correlation between the start date of the hazel pollen season and accumulated mean, minimum and maximum temperature were calculated in different periods preceding the season $(20,15,10,5$ days before the season). Only positive temperature was taken into account in the analysis. The highest correlation coefficient with a value of -0,76983 was obtained for 5-day mean temperature before the season, which means that the higher mean air temperature is right before pollen shedding, the earlier the pollen season starts (Tab. 3).

Table 3

Coefficients of correlation between the start of the hazel pollen season and accumulated mean, minimum and maximum air temperature in different periods before the season.

\begin{tabular}{cccc}
\hline $\begin{array}{c}\text { Number of days before } \\
\text { the season }\end{array}$ & Mean temp. & Min temp. & Max temp. \\
\hline 20 & $-0,68535$ & $-0,7426^{*}$ & $-0,56446$ \\
\hline 15 & $-0,688$ & $-0,66776$ & $-0,51248$ \\
\hline 10 & $-0,66343$ & $-0,6446$ & $-0,46672$ \\
\hline 5 & $-0,76983^{*}$ & $-0,74992^{*}$ & $-0,66387$ \\
\hline
\end{tabular}

* correalation coefficient statistically significant $(\mathrm{p}<0.01)$

The multiple regression analysis showed that, in addition to air temperature, in particular one of its characteristics which is the number of days with mean daily temperature below zero, total precipitation in the period from 1 October to the start of the pollen season also plays an important role (see Tab. 2). equation:

This correlation can be seen in the following

$$
\mathrm{PS}=0.24 \sum \mathrm{p}+0.41 \sum \mathrm{N}_{\mathrm{d}} \mathrm{t}_{\text {mean }}<0-11.98
$$

PS - season start

$\Sigma \mathrm{p}$ - total precipitation from 1 October to the start of the pollen season

$\sum \mathrm{N}_{\mathrm{d}} \mathrm{t}_{\text {mean }}<0-$ number of days with mean daily temperature below $0^{\circ} \mathrm{C}$, from 1 October to the start of the pollen season
As a result of the regression analysis, a high adjusted determination coefficient $\mathrm{R}^{2}=0.95$ was obtained. Thus, the derived model explains about $95 \%$ of the variability in the start dates of hazel pollen seasons. This means a very good correlation between the abovementioned parameters. No significant influence of the other meteorological factors was found.

In order to verify the reliability of the derived model, the predicted start date of the hazel pollen season was determined for the year 2009. The 2009 meteorological data were used which were not incorporated in the model equation. The obtained result was equally good as in the case when these data were incorporated. A comparison of the actual season start dates with the values calculated using the model, describing the correlation between the season start and meteorological conditions, gives a very good result (Fig. 3). 


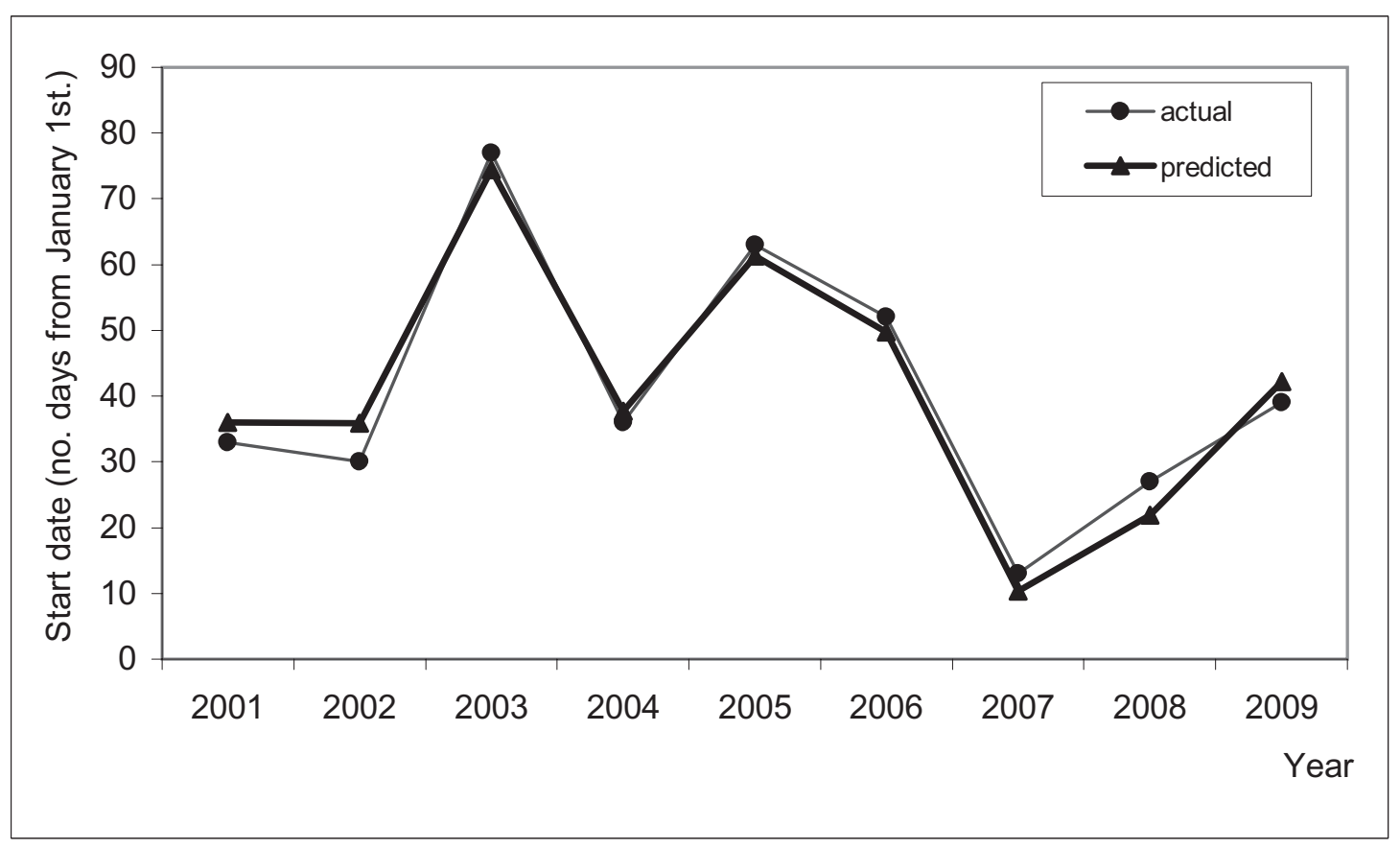

Fig. 3. The start date of the hazel pollen season - actual vs. model-predicted values.

\section{DISCUSSION}

Pollen shedding dates for early spring flowering plants are characterised by great variability. Over the 9-year study period, the start of the hazel pollen season was noted in Lublin in the period from January to March; the differences were 64 days, but they can be even larger. In 1996, due to low temperatures, hazel pollen was recorded as late as the second week of April (P i o trow s k a, 2006). There are fluctuations between particular years as well as particular regions. In the studies conducted in 7 centres in Poland, it was found that the hazel pollen season in the same year (1995) started earliest in the second decade of January (in Poznań), whereas it started latest at the beginning of March (in Gdańsk) (K a s p r z y k et al. 2004).

In countries with moderate climate, air temperature recorded at the end of winter and in early spring has the greatest influence on the onset of the pollen season. Before flowering, trees and shrubs require heat accumulation. Anther opening occurs after the absorption of a specific dose of thermal energy (so-called cumulative temperature) (Frenguelli et al. 1992; Minero et al. 1999; Gonzalez-Parrado et al. 2006). The heat requirement is usually determined genetically and it is different for particular plant species (Frengue 11 i et al. 1991). For trees flowering at the turn of winter and spring, it is difficult to find a correlation between accumulated temperature and the start of the season $(\mathrm{Gonzalez}-\mathrm{Mine}$ ro et al.
1999; D ą b r o w s k a - Z a p a r t, 2008). Statistically significant correlations occur much more frequently in the case of later flowering taxa (S t a c h et al. 2002).

Our own phonological observations demonstrate that hazel pollen release may start already in the period of negative temperatures. It relates equally to mean, minimum and maximum temperature. In the study it was shown that accumulated 5-day mean air temperature before the season plays an important role for the start date of the hazel pollen season.

In Lublin in the years 2001-2009, among the meteorological factors studied, precipitation and number of days with subzero temperature had the most significant effect on the start of the hazel pollen season. But Dąbrowska-Zapart (2008) found in the conditions of Sosnowiec a high correlation between the abovementioned characteristic of the season and mean, minimum, maximum temperature, relative humidity and number of days with subzero temperature. According to U r u s k a (2003), the start of the Alnus pollen season depends on the number of days with negative temperature from the beginning of the year.

In earlier studies carried out in Lublin, the influence of meteorological conditions on the start date of the hazel pollen season in different time intervals was investigated ( $\mathrm{Piotrowska}$ and $\mathrm{Kaszewski}$, 2007). As a result of regression analysis, a predictive model was derived, in which one statistically significant element (out of 8 considered) was the number of days with negative temperature from 1 January. 
In the present study, the effect of weather conditions was taken into account over the period from 1 October until the start of the season. A higher adjusted determination coefficient was obtained $\left(\mathrm{R}^{2}=0.95\right)$ than in the earlier studies $\left(\mathrm{R}^{2}=0.92\right)$.

The regression model derived in this study seems to be precise to a large extent; however, it should be updated from year to year in order to confirm or verify the data.

\section{CONCLUSIONS}

1. In the years 2001-2009, the hazel pollen season in Lublin started earliest on 13 January and latest on 18 March.

2. The number of days with subzero temperature as well as precipitation in the period from 1 October had the greatest influence on the season start date.

3. The start of the hazel pollen season also depended on accumulated mean air temperature for the period of 5 days preceding the season.

\section{Acknowledgments}

This study was partially financed by research funds for the years 2009-2011 as a research project 3219/B/P01/2009/36. We would like to express our gratitude to dr Agnieszka Uruska for her assistance in statistical calculation.

\section{REFERENCES}

Adams-Groom B., Emberlin J., Corden J., Millington W., Mullins J., 2002. Predicting the start of the birch pollen season at London, Derby and Cardiff, United Kingdom, using a multiple regression model, based on data from 1987 to 1997. Aerobiologia, 18: 117-123.

Dąbrowska-Zapart K., 2008. The influence of meteorological factors on the hazel (Corylus L.) pollen concentration in Sosnowiec in the years 1997-2007. Acta Agrobot. 61 (2): 49-56.

Emberlin J., Smith M., Close R., Adams-Groom B., 2007. Changes in the pollen seasons of the early flowering trees Alnus spp. and Corylus spp. in Worcester, United Kingdom, 1996-2005.

Filon F. L., B osco A., B arbina P., Sauli M. L., Rizzi L on g o L., 2000. Betulaceae and Corylaceae in Trieste (NE-Italy): Aerobiological and clinical data. Aerobiologia, 16: 87-91.

Frei T., 1998. The effects of climate change in Switzerland 1969-1996 on airborne pollen quantities from hazel, birch and grass. Grana, 37: 172-179.

Frenguelli G., Spieksma F.TH.M., Bricchi E., Romano B., Mincigrucci G., Nikkels A. H., Dankaart W., Ferranti F., 1991. The influence of air temperature on the starting dates of the pollen season of Alnus and Populus. Grana, 30: 196-200.

Frenguelli G., Bricchi E., Romano B., Mincigrucci G., Ferranti F., Antognozzi E., 1992. The role of air temperature in determining dormancy release and flowering of Corylus avellana L. Aerobiologia, 8: 415-418.

Gonzalez-Minero F.J. Morales J., Tomas C., Candau P., 1999. Relationship between air temperature and the start of pollen emission in some arboreal taxa in Southwestern Spain. Grana, 38: 306-310.

Gonzalez-Parrado Z., Fuertes-Rodriguez C. R., Vega-Maray A. M., Valencia-Barrera R. M., Rodriguez-Rajo F. J., Fernandez-Gonzalez D., 2006. Chilling and heat requirements for the prediction of the beginning of the pollen season of Alnus glutinosa (L.) Gaertner in Ponferrada (León, Spain). Aerobiologia, 22: 47-53.

Hofman T., Michalik J., 1998. Alergia pyłkowa. Total Druk Poznań.

Kasprzyk I., Uruska A., Szczepanek K., Latałowa M., Gaweł J., Harmata K., Myszkowska D., Stach A., Stępalska D., 2004. Regional differentiation in the dynamics of the pollen seasons of Alnus, Corylus and Fraxinus in Poland (preliminary results). Aerobiologia, 20: 141-151.

Kn ox R. B., S u phi o gl u C., 1996 b. Pollen allergens: development and function. Sex. Plant Reprod., 9: 318-323.

Matthiesen F., I psen H., Lřwenstein H., 1991. Pollen allergens. [In:] G. D’Amato, F. Th. M. Spieksma, S. Bonini (eds), Allergenic pollen and pollinosis in Europe: 36-44, Blackwell Sci. Publ., Oxford.

Minero G. F. J., Morales J., Tomas C., Candau P., 1999. Relationship between air temperature and the start of pollen season emission in some arboreal taxa in Southwestern Spain. Grana, 38: 306-310.

Piotrowska K., 2006. Kalendarz pyłkowy dla Lublina, 1995-2000. / Pollen calender for Lublin. Acta Agrobot. 59 (1): 529-538.

Piotrowska K., Kas zewski B. M., 2007. Początek sezonu pyłkowego leszczyny a warunki meteorologiczne. / The start of the hazel pollen season and meterological conditions. Streszczenia. VI Ogólnopolska Konferencja Naukowa „Biologia kwitnienia roślin i alergie pyłkowe", Lublin, 8-9 listopada 2007: 61.

P u c M., 2007. The effect of meteorological conditions on hazel (Corylus spp.) and alder (Alnus spp.) pollen concentration in the air of Szczecin. Acta Agrobot., 60 (2): 65-70.

Rapiejko P., 2007. Alergeny pyłku leszczyny. / The hazel pollen allergens. Alergoprofil, 3 (2): 24-29.

Rodriguez-Rajo F. J., Dopazo A., Jato V., 2004. Environmental factors affecting the start of pollen season and concentrations of airborne Alnus pollen In two localities of Galicia (NW Spain). Ann. Agric. Environ. Med. 11: $35-44$.

Stach A., Czarnecka-Operacz M., Nowaczyk B., Silny W., 2002. The influence of weather conditions 
on the course of pollen seasons for chosen taxa in Poznań in 2000. Ann. UMCS Sect. EEE, X: 139-146.

Stanisz A., 2000. Przystępny kurs statystyki z wykorzystaniem programu Statistica na przykładach z medycyny. StatSoft, Kraków.

Uruska A., 2003. The influence of selected meteorological factors on variation of tree pollen counts in the air in Gdańsk. Ann. UMCS Sect. EEE, XIII: 293-301.

Weryszko-Chmielewska E., Rapiejko P., 2007. Analysis of Alnus spp. pollen seasons in Lublin and Warszawa (Poland), 2001-2007. Acta Agrobot. 60 (2): 87-97.

\section{Wpływ warunków meteorologicznych na początek sezonu pyłkowego leszczyny (Corylus L.) w Lublinie, 2001-2009}

\section{Streszczenie}

Rośliny kwitnące wczesną wiosną z powodu dużej zmienności pogody w okresie poprzedzającym kwitnienie, wykazują duże różnice w terminach rozpoczęcia pylenia. W pracy analizowano wpływ warun- ków meteorologicznych na termin rozpoczęcia sezonu pyłkowego leszczyny w Lublinie w latach 2001-2009. Badania aeropalinologiczne prowadzono metodą wolumetryczną z zastosowaniem apararu Lanzoni VPPS 2000. Początek sezonu pyłkowego leszczyny wyznaczono metodą 98\%. Różnice w poszczególnych latach badań wynosiły ponad dwa miesiące. Najwcześniej rejestrowano ziarna pyłku leszczyny w roku 2007, gdyż od 13.01, a najpóźniej w roku 2003, od 18.03. Stwierdzono, że skumulowana średnia temperatura z 5 dni przed sezonem ma wpływ na rozpoczęcie sezonu pyłkowego. W wyniku analizy regresji wielokrotnej otrzymano statystyczny model deterministyczny, który z dużą dokładnością pokazuje związek początku sezonu pyłkowego leszczyny z sumami opadów atmosferycznych i liczbą dni zimowych. 